\section{Steam Powered Cable Car Remove the Barrier of Traffic Congestion in Densely Populated Cities}

\section{J. B. Veeramalini, B. Bharathiraja, J. Jenish Joyal, S. Raghu Vinayak, V. Naveen}

Department of Chemical Engineering, Vel Tech High Tech Dr. Rangarajan Dr. Sakunthala Engineering College, Avadi, Chennai, Tamil Nadu, India

\section{Address for} correspondence: J. B. Veeramalini, Department of Chemical Engineering, Vel Tech High Tech Dr. Rangarajan Dr. Sakunthala Engineering College, Avadi, Chennai-600 062, Tamil Nadu, India. E-mail: veeramalini@gmail. com

Keywords:

Delhi smog, Water scarcity, Water purification, Cable car, Population

Received: $02^{\text {nd }}$ February 2019 Accepted: $28^{\text {th }}$ February 2019 Published: 07 ${ }^{\text {th }}$ March 2019

\section{INTRODUCTION}

The most exploiting powerful source of energy for the survival of human is water and with water purification technology the needs of water are not meet up with the measurable one. Although some technological innovation with multiple stage water purifiers has been introduced it fails to supply ample quantity of drinking water, the byproduct emission of wastewater seems to be a greater threats. ${ }^{[1-3]}$ To treat that wastewater it is again be a great impact on societal in-terms of economic come environmental risk factors. Under these measures, the work is carried out to save one of the Seven Wonders of the World, the Taj Mahal. Delhi has a population of over 18.98 Million while it covers only a small area of 1,484 $\mathrm{km}^{2}$. It is the third largest city in the world. It is also the second largest metropolis after Mumbai. The National Capital Territory comprised nine districts, 158 villages and 62 towns. Being the Capital of India, Delhi is the center stage of all political activities. Each year Delhi has a huge number of tourists. The sites of interest are categorized into three areas. First, the British build New Delhi with all its government buildings. Second, all the historical monuments have been left by the dynasties, who ruled Delhi. At third place, there are some great religious places.
Some of the worth visiting places are - India Gate, Rashtrapati Bhavan, Red Fort, Qutub Minar, Humayun's tomb, Jama Masjid, Jantar Mantar, Laxmi Narayan Mandir, Birla Mandir, Lotus Temple, etc. In Delhi, Tourist and Transportation Development Corporation Limited conducts city sightseeing and excursion tours. The corporation has also introduced adventure tourism activities such as Para-sailing, rock climbing and boating in Delhi. The corporation has also developed "Delhi Haat" where beverages and food items of different states are available in one place. More such Haats are planned in different parts of Delhi. The "Garden of Five Sense" in south Delhi also attracts a lot of tourist. These are vital factors for the great increase of pollution and in turn, create a large problem for the survival of human life. ${ }^{[4-6]}$ And also the tremendous increased population has led to many problems in the capital of our nation. One such problem is the recent smog in Delhi due to increased air pollution. Consequences of air pollution results in premature deaths of 10,000 people a year and also the world famous Taj Mahal is a victim of this chronic pollution. ${ }^{[7]}$ Several policy frameworks and technology have been adapted to account the air pollution in combined effects of multiple airs emit of particulate matter. Further the specific pollutant of reducing mechanism in air pollution, where under target pollutant removal in air and its 
futuristic effects. Thus the combined effect is defined as synergetic effects of pollutants removal at the technology level has often been neglected by using steam power cable car. ${ }^{[7-8]}$ In the past three decades, the air pollution control strategy in China initially control target level of one pollutant for certain duration through the single-pollutant control. ${ }^{[6-9]}$ Total suspended particulate, the main focus of the government, has been on acid rain of pollution and acids emissions in the decades of the mid-1980s to the mid-1990s. Later on, it was control focused on the reduction in the 2000s that smog emission as acid rain. When haze issues come to critical in the year of 2010 in the cities of Delhi, due to the emission of particulate matter of level $\left(\mathrm{PM}_{2.5}\right)$ started to be addressed and was given great attention in air pollution control policies.

Thus, today, one of the major threats to the welfare of the people of Delhi and the city is the various types of pollution. ${ }^{[8]}$ The pressure and haphazard growth of the population are deteriorating the environment. It has also been reported that the number of vehicles plying on the roads of Delhi is more than that of the three metropolitan cities of Mumbai, Kolkata, and Chennai taken together and in international threats too. ${ }^{[9,10]}$ There has been no proper technology or methods to treat solid, liquid wastewater, industrial and hospital wastes in the city. Contrary to popular belief, most of the air pollution in Delhi is mainly by uncontrollable vehicular traffic. Furthermore, there is a need to provide drinking water to this enormous populated region which seems to be more challenging. To control the pollution in Delhi and to treat its water scarcity, this project will be beneficial. Here, the purification of salt water or sewage water can be possible by this method. ${ }^{[11]}$ As a by-product from this plant, an environmentally acceptable electric drive is coupled with it. It is none other than the Cable Car is developed in this research project.

\section{METHODOLOGY}

Selective treatment of wastewater by removal large suspended solids by the sedimentation technique. Further, the hardness of the treated water is to be removed and then subjected to an evaporator, thereof complete removal of brine is occurred. Thus, the two-way mechanism of generation of electricity through the turbine and further conversion of steam into pure water by coolant in the condenser is optimized. ${ }^{[12,13]}$ Thus, global Environmental Performance Index 2014, India, has reached a rank of 155, slipped 32 ranks from the previous year, and it is disheartening to hear that Delhi, the national capital of the country, is being tagged as one of the most heavily polluted cities in the world. It is the worlds worst city for air pollution ratio as $87 \%$ is recorded on average as mentioned in Figure 1 and Table 1.

From the above methodology, the water supply to the city would increase and thereof emission of pollution is reduced to a large extent. ${ }^{[14,15]}$ Though the effective motor operation ${ }^{[14]}$, is in practice, but the cable car has been driven under the limited space under zero pollutants of sustainable environment.

\section{RESULTS}

In this work, the technological transition is developed to reduce pollution in highly polluted cities, Delhi and to clear of road dust. Further, the work is extended to provide pure water

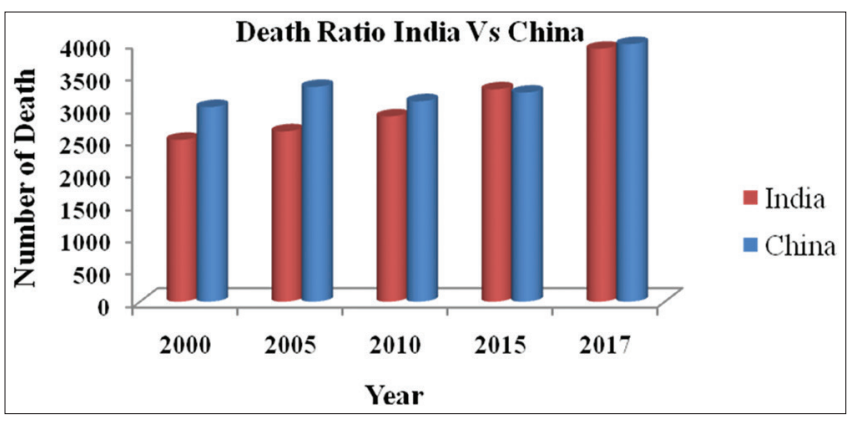

Figure 1: A bar chart showing deaths due to air pollution

Table 1: Air pollution death rate in India versus China

\begin{tabular}{ccc}
\hline Year & $\begin{array}{c}\text { No. of death count } \\
\text { in India }\end{array}$ & $\begin{array}{c}\text { No. of death count in } \\
\text { China }\end{array}$ \\
\hline 2000 & 2502 & 3010 \\
2005 & 2634 & 3321 \\
2010 & 2865 & 3100 \\
2015 & 3283 & 3283 \\
2017 & 3912 & 3985 \\
\hline
\end{tabular}

to the citizens of the city and also to decrease the congestion in the city by the generation of the Steam Powered Cable Car and their utilization aspects. ${ }^{[16]}$

A city population of half a million gives away 85 Million liters a day. A portion of these wastewaters can be collected in a sedimentation tank. A sedimentation tank allows suspended particles to settle out of water or wastewater as it flows slowly through the tank, thereby providing some degree of purification. Alum is added here to remove turbidity of the water. ${ }^{[17,18]}$ A layer of accumulated solids, called sludge, forms at the bottom of the tank and is periodically removed. The remaining solid-free water is then allowed to flow through a tank which contains either an acidic solution or an alkaline solution depending on the $\mathrm{pH}$ of the wastewater. If the $\mathrm{pH}$ is $<7$, the alkaline solution is added until its $\mathrm{pH}$ becomes neutral. If the $\mathrm{pH}$ is $>7$, the acid solution is added until its $\mathrm{pH}$ becomes neutral. ${ }^{[19,20]}$ This hardness removed treated water is then sent to an evaporator. This evaporator consists of an inlet, a turbine, and an outlet. The treated water is heated until it reaches $135^{\circ} \mathrm{C}$. This temperature is sufficient for the generation of superheated steam. Continues generation of superheated steam results in the development of high pressure inside the evaporator, it is used to run the turbine. The rest of superheated steam which does not collide with the turbine moves to a condenser and cools down to form pure water. ${ }^{[21,22]}$ Then, the turbine is coupled with a generator to convert the mechanical energy into electrical energy which is utilized by the environmentallyacceptable electrical drive, the Cable Car. ${ }^{[23]}$ Remaining 73\% of the brine solution inside the process chamber is periodically removed from the evaporator through the outlet valve and the simplified flow chart of the above process is shown in Figure 2.

\section{DISCUSSION}

The Cable Car finds out an effective solution to the current situation in Delhi. The Delhi roadways stretch for about 


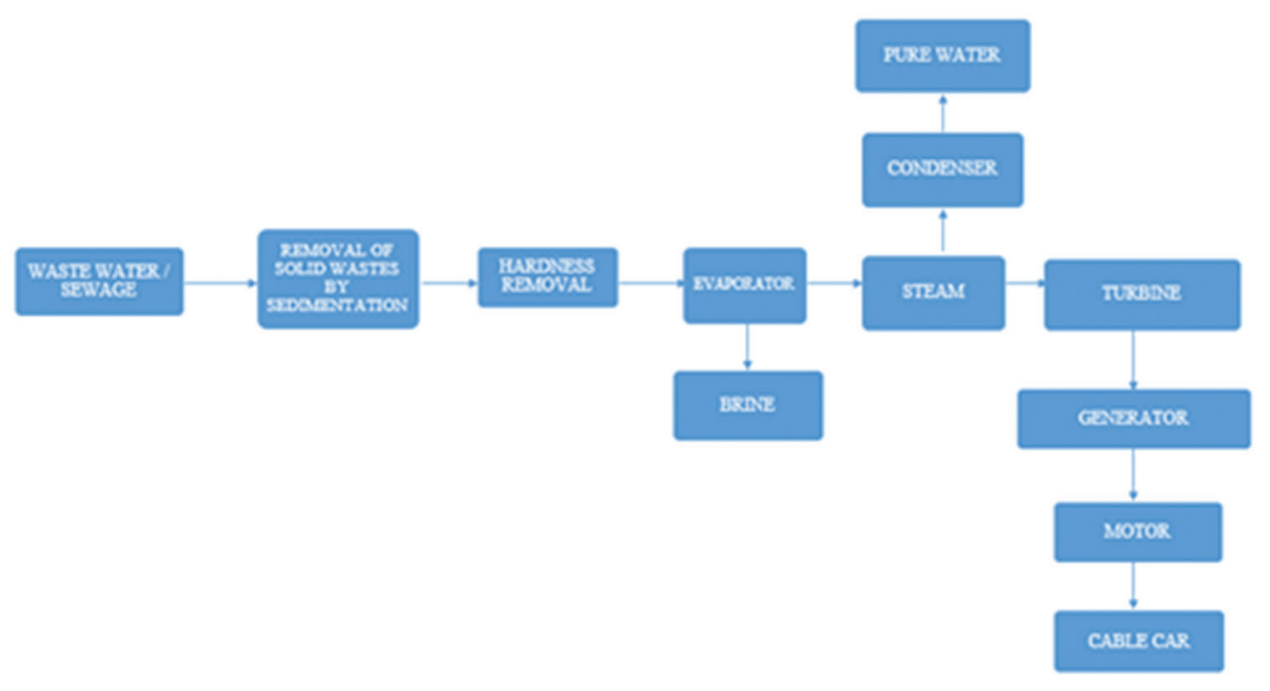

Figure 2: Process flow chart for steam-powered Cable Car

$28,508 \mathrm{~km}$. This distance can be easily covered by 679 Cable Cars. The Cable Car vehicles are motor-less and engine-less and they are pulled by a cable that is rotated by a motor off-board. Hence, there is no passage of electricity on the cable. ${ }^{[24-26]}$ It can also stop in desirable stations. Within two cable poles, the average distance is $7 \mathrm{~km} .{ }^{[27]}$ They are light in weight and require no drivers. Hence, fewer operators are enough for Cable Car operation. ${ }^{[28,29]}$ They can run at an average speed of $45 \mathrm{kmph}$. Large aerial Cable Cars can transport 4000 peoples in a single direction. ${ }^{[30]}$ It is the safest mode of transport than other road transports.

\section{CONCLUSION}

Predominant contributors of particulate matter emission and in contamination with the air in negotiation with the unusual atmospheric weather conditions are predictable in Delhi city. In recent reports it clearly constituted heavy particulates in the month of November-March. Thus, switching of sulfur fuels to steam power deteriorates stagnation level in air and also reduces the pollution control to a great extent. Large number of individuals is improved significantly apparently improved the utilization of steam power Cable Car together with water purification system is greatly adopted to meet the requirements. A suitable for marine water purification together with a single steam-powered Cable Car plant, 0.59 L of pure water can be cultivated from $1 \mathrm{~L}$ of saline water or sewage water. Thus, the await of technical development of an local weather condition to save our capital from the prevailing air pollution, and to provide the citizens pure water and steam-powered Cable Car.

\section{REFERENCES}

1. Hutton G, Haller L. Evaluation of the Costs and Benefits of Water and Sanitation Improvements at the Global Level. Geneva: World Health Organization; 2004. p. 65.

2. Smith AH, Lingas EO, Rahman M. Contamination of drinkingwater by arsenic in Bangladesh: A public health emergency. Bull World Health Organ 2000;78:1093-103.

3. Liu B, Ma Y, Gong W, Zhang M. Observations of aerosol color ratio and depolarization ratio over Wuhan. Atmos Pollut Res 2017; 8:1113-22.
4. Ma J, Chen Y, Wang W, Yan P, Liu H, Yang S, et al. Strong air pollution causes widespread haze-clouds over China. J Geophys Res Atmos 2010;115:1-21(D18204).

5. Tao M, Chen L, Wang Z, Ma P, Tao J, Jia S. A study of urban pollution and haze clouds over northern China during the dusty season based on satellite and surface observations. Atmos Environ 2014; 82:183-92.

6. Ramanathan V, Crutzen PJ, Kiehl JT, Rosenfeld D. Aerosols, climate, and the hydrological cycle. Science 2001;294:2119-24.

7. Harrison RM, Yin J. Particulate matter in the atmosphere: Which particle properties are important for its effects on health? Sci Total Environ 2000;249:85-101.

8. Vardoulakis S, Kassomenos P. Sources and factors affecting PM10 levels in two European cities: Implications for local air quality management. Atmos Environ 2008;42:3949-63.

9. Zeng J, Xing M, Hou M, England GC, Yan J. How best management practices affect emissions in gas turbine power plants-an important factor to consider when strengthening emission standards. J Air Waste Manag Assoc 2018;68:945-57.

10. He H, Wang Y, Ma Q, Ma J, Chu B, Ji D, et al. Mineral dust and NOx promote the conversion of $\mathrm{SO} 2$ to sulfate in heavy pollution days. Sci Rep 2014;4:4172.

11. Zhang Q, Duan JN, Tie X, Li X, Liu Q, Gao Y, et al. Effects of meteorological and secondary particle formation on visibility during heavy haze events in Beijing, China. Sci Total Environ 2015; 502:578-584.

12. Zheng GJ, Duan FK, Su H, Ma YL, Cheng Y, Zheng B, et al. Exploring the severe winter haze in Beijing: The impact of synoptic weather, regional transport, and heterogeneous reaction. Atmos Chem Phys 2015;15:2969-83.

13. Brook RD, Brook JR, Urch B, Vincent R, Rajagopalan S, Silverman F. Inhalation of fine particulate air pollution and ozone causes acute arterial vasoconstriction in healthy adults. Circulation 2002;105:1534-6.

14. Gluck SJ, Glenn C, Logan T, Vu B, Walsh M, Williams P. Evaluation of $\mathrm{NO}_{\mathrm{X}}$ flue gas analyzers for accuracy and their applicability for low-concentration measurements. J Air Waste Manag Assoc 2003; 53:749-58.

15. Hao J, Wang L, Shen M, Li L, Hu J. Air quality impacts of power plant emissions in Beijing. Environ Pollut 2007;147:401-8.

16. Xu X, Ge B, Lin W. Progresses in the research of ozone production efficiency (OPE). Adv Earth Sci 2009;24:845-53.

17. Klumpp A, Ansel W, Klumpp G, Vergne P, Sifakis N, Sanz MJ, et al. Ozone pollution and ozone biomonitoring in European cities 
Part II. Ozone-induced plant injury and its relationship with descriptors of ozone pollution. Atmos Environ 2006;40:7437-48.

18. Gu J. Application of SDA desulfurization technology system. China Environ Prot Ind 2007;6:38-42.

19. Deng W, Liu R, Xiong J, Chen H, Tian H, Du Z. Research progress of acid rain in China. Meteorol Environ Sci 2009;32:82-7.

20. He KB, Yang FM, Yu XC, Cadle SH. Characterization of urban air pollution sources. Urban Environ Urban Ecol 2003;16:269-71.

21. Wang G, Zhang R, Gomez ME, Yang L, Levy Zamora M, Hu M, et al. Persistent sulfate formation from London fog to Chinese haze. Proc Natl Acad Sci U S A 2016;113:13630-5.

22. Quan J, Tie X, Zhang Q, Liu Q, Li X, Gao Y, et al. Characteristics of heavy aerosol pollution during the 2012-2013 winter in Beijing, China. Atmos Environ 2014;88:83-9.

23. Zhang JK, Sun Y, Liu ZR, Ji DS, Hu B, Liu Q, et al. Characterization of submicron aerosols during a month of serious pollution in Beijing, 2013. Atmos Chem Phys 2014; 14:2887-903.

24. Testo. Detailed Equipment Description of Testo 350; 2017. Available from: http://www.testo350.com/testo350-turbinetesting.html. [Last accessed on 2017 Apr 27].

25. Lin $\mathrm{P}, \mathrm{Hu} \mathrm{M}$, Deng Z, Slanina J, Han S, Kondo Y, et al. Seasonal and diurnal variations of organic carbon in PM2.5 in Beijing and the estimation of secondary organic carbon. J Geophys Res 2009; 114:1-14(DOOG11).
26. Reich PB. Quantifying plant response to ozone: A unifying theory Tree Physiol 1987;3:63-91.

27. Kampa M, Castanas E. Human health effects of air pollution. Environ Pollut 2008;151:362-7.

28. Huang RJ, Zhang YL. High secondary aerosol contribution to particulate pollution during haze events in China. Nature 2014; $514: 218-22$.

29. Macías P, Islas J. Damage costs produced by electric power plants: An externality valuation in the Mexico City Metropolitan Area. Sci Total Environ 2010;408:4511-23.

30. Swart R, Amann M, Raes F, Tuinstra W. A good climate for clean air: Linkages between climate change and air pollution. An editorial essay. Clim Change 2004;66:263-9.

Cite this article: Veeramalini JB, Bharathiraja B, Joyal JJ, Vinayak SR, Naveen V. Steam Powered Cable Car Remove the Barrier of Traffic Congestion in Densely Populated Cities;5(1):30-33.

Source of Support: Nil, Conflict of Interest: None declared. 